\title{
On the Opportunities and Choices in the Transformation of Private Higher Education Institutions and Independent Colleges in China --Take City College of Wuhan University of Science and Technology as an Example
}

\author{
Siyou Zhang ${ }^{1,}$, Lijuan Qiu ${ }^{1}$ \\ ${ }^{1}$ City College, Wuhan University of Science and Technology, Wuhan, Hubei Province, China \\ a1585143263@qq.com
}

Keywords: Private Higher Education; Independent College; Transformation; Opportunity; Choice.

\begin{abstract}
According to the needs of the development strategies of our country, the State Council made the decision that some universities and colleges should make the transformation to the applied technology university. The private higher education institutions and independent colleges are a part of the higher education as a whole, and they are the main body of the transformation as well. The transformation is inevitable, but how to make clear the goal and choose the right way is a question. This paper takes City College of Wuhan University of Science and Technology as an example, points out that in order to meet the needs of regional economic development and the students' job requirements and their essential capability in employment after graduation, the independent colleges should do the following things: 1 ) to reform the professional curriculum system; 2)to put emphasis on practical education; 3) to insist on building the practice and training center with enterprise together; 4) to train a teaching staff with double-professions both in teaching and other fields; 5) to strengthen students' ability of both innovation and entrepreneurship. Only by applying the measures mentioned above, can the private higher education institutions and independent colleges in China seize the opportunities and realize their transformation.
\end{abstract}

\section{Introduction}

In the State Council Executive Meeting held in February 2014, Premier Ke-qiang Li proposed "to guide a number of regular undergraduate colleges and universities to become applied technique-oriented institutions". This marks the official reform and development of applied technique-oriented colleges and universities in higher education in China. In April 2014, Hubei Provincial Department of Education issued "Document on carrying out pilot work in the restructuring and developing undergraduate colleges and universities in Hubei Province". During the National People's Conference (NPC) and the Chinese People's Political Consultative Conference (CPPCC), Premier Ke-qiang Li stressed again in the government report that we should guide a number of regular undergraduate colleges and universities to become applied technique-oriented institutions. Gui-ren Yuan, Minister of Education, also regarded promoting the construction and development of undergraduate colleges and universities as the key work in 2015. Government and education sectors hold an insistent attitude to the transformation. Accelerating the construction of modern vocational education system and training qualified application-oriented talents have become the consensus of the government, schools and society.

With the development of economy and society, higher education in China has been more and more popular. Promoting the development of undergraduate colleges and universities has been an important part of higher education reform. Many private colleges and independent colleges choose basing on local place, industry docking, school-enterprise cooperation and special guiding principle for running a school. They have become the major force in the transformation. However, what opportunities and challenges will the private colleges and independent colleges and universities meet during the transformation? In this paper, we take City College of Wuhan University of Science and Technology as an example with an aim to explore these issues. 


\section{The opportunities during the development of applied technique-oriented colleges and universities}

At present, the phenomenon of the students' difficult job employment and the enterprises' difficult recruitment is common, which suggest that the college graduates cannot meet the social demand for talent. The demand of the application-oriented talents working in production line exceeds the supply. The shortage of application-oriented talents has aroused great attention of the state and society.

Running experience of developed countries has shown that the development of applied technique-oriented colleges and universities is the requirement of historical trend. The history of the development of higher education in developed countries has shown that the applied technique-oriented colleges and universities are an irresistible trend of history. It has formed a mature development experience. These colleges and universities have their won the reputation. They have even been superior to the academic universities and become the main part of higher education. In the UK, since the establishment of University of London in 1828, higher education of applied technique-oriented has become flourished, setting off a new round of new university movements which seek to implement scientific education and train applied technique-oriented talents. In Germany, after World War II, the reconstruction of the country shows a serious lack of applied technique-oriented talents. Thus, the federal government had to take action against some schools to implement the merger, to establish the applied technique-oriented university. Since the date of birth, it shows vitality. Today, the proportion of applied technique-oriented talents and academic-oriented talents in German is 8:2. In the United States, since the 19th century, the land-grant colleges have appeared and the applied technique-oriented colleges and universities have flourished. In each state of the United States, there are more than a dozen of colleges and universities. But each state has only a few academic universities while the rest are community colleges training applied technique-oriented talents [1]. China's higher education of applied technique-oriented started later than the developed countries. It is still at the exploratory stage of development. At present, there are no well-known applied technique-oriented colleges and universities. In addition, because of the different space-time environment compared to foreign countries, we cannot simply copy the mature experience of foreign schools. This provides the private higher education institutions and independent colleges great opportunities. Those aimed to become applied technique-oriented institutions and put into practice will rapidly become famous domestic applied technique-oriented colleges and universities.

It is the need of profound changes in economic development for the private higher education institutions and independent colleges to transform into applied technique-oriented colleges and universities. Economic development is the most powerful driving force for private higher education institutions and independent colleges' transformation and development. To develop with regional economy is the private higher education institutions and independent colleges' value. China's current economic development mode is fast changing. The industrial structure has been deeply adjusted the real economy has been developing rapidly. The demands for talents, technology and professional structure have undergone great changes, which become the external motivation of higher education in structural adjustment and classification management. Economic development requires higher education to carry classification reform. The formation of higher education structure which matches the industrial structure and social development is imperative. To promote the reform of traditional industries and new industries, one type of the universities must more deeply integrate into the innovation system of the regional economic development, accurately grasp the pulse of industrial development, service the enterprises in production line, quickly provide people with warm services, focus on the technology innovation and the practical problems of Internet revolution and application in personnel training and scientific research. Therefore, different from the academic 985 and 211 universities, private higher education institutions and independent colleges will be the best the choices become the best choice for transformation. [2]

It is the internal requirement of the development of the private higher education institutions and independent colleges. Social development needs both academic talents and applied technique-oriented talents. With the popularization of higher education in China, in 2015, China has 
1219 independent undergraduate institutions with enrollment eligibility. The guidance of national policy level is not enough. Thus, many undergraduate colleges and universities have similar development goals. Their school running and features are not clear. They simply copy the system of old universities with long history. Due to the schools' history, the quality of students, hardware conditions, faculty, funding and so on, it results in the problem that many schools without a long history are not able to keep pace with the veteran academic universities. From the actual development, the private higher education institutions and independent colleges cannot copy the running way of the academic universities. Therefore, the private higher education institutions and independent colleges should have reasonable positioning, be based on local situation, train applied technique-oriented talents with theoretical knowledge, strong practical ability, sense of innovation and spirit of innovation for the development of local economy and society [3].

\section{The choices the applied technique-oriented undergraduate universities face during their development}

How to respond to national calls and deal with the transformation and development is the focus of training high-qualified and applied technique-oriented talents of the private higher education institutions and independent colleges.

Based on the local situations and industry docking. For the private higher education institutions and independent colleges, training talents for regional economic and social development is a country's requirement, as well as the parents and students' expectations. These universities should fully investigate into the current situation of regional economic development and direction, the actual demand for talents, so that they can solve the practical problems in regional economic transformation and development. For example, the target of private higher education and independent universities to be based on the situations of Hubei, "Two Area One Belt" of Hubei Province and "1 +8 city circle" of Wuhan. According to the industry structure of Hubei Province high-tech industry, modern service industry, modern culture industry, as well as the actual requirements of the students' development and the enterprises' social needs, we carry out scenario simulation teaching inside the college and internships outside the college. A training base established by the college and enterprise is also carried out. We train talents with good ideological quality, basic theoretical knowledge, strong practical ability, innovative thought and innovation spirit, which is also the orientation of applied technique-oriented universities. The college has formed the school running features of training new typed talents catering to technology industry, frontline talents of modern manufacturing industry, talents of modern society management and qualified talents of modern service industry. Since the establishment in 2002, the college has gained great achievements. According to the release issued by iResearch Chinese Alumni Network, the comprehensive strength ranking of Chinese independent colleges, our college ranked the seventh in all the national independent colleges in 2015. There is only one college in Hubei Province ranking the national top 10. And this is also the first time that our college ranked the eighth among all the national independent colleges in 2013 and 2014. We keep in the first-rate among national independent colleges. Our college has won the rewards of China's Exemplary Independent College, Top 10 Comprehensive China Independent College, China's Exemplary College with Innovative Graduates among Independent Colleges.

To reform the innovative talent training mode and focus on the transformation of applied competence. Specialty setting and applied technique-oriented institutions. To training applied technique-oriented talents, specialty setting is quite essential. In City College of Wuhan University of Science and Technology, specialty setting is based on the economic and social structure of Hubei Province. The college decisively closed the majors whose employment situation is not good in recent years, such as law, product design and set some new majors, machinery manufacturing and automation, construction costs, civil engineering, pharmaceutical preparations, automotive engineering and so on. These closely combine the specialty setting with the needs of economic development of Hubei Province, and make ithem real applied technique-oriented majors. Some majors in the college, for instance, computer science and technology, mechanical engineering and automation, nursing, logistics management, accounting, business administration, civil engineering 
and construction costs are closely related to the economic and industry development of Hubei Province. In recent years, all the students of nursing are able to gain Nurse Qualification and 99\% of them can get the job. And the majority of the students sign the contract with Zhongnan Hospital, Tongji Hospital, Union Hospital, Provincial People's Hospital and other large hospitals within province before their graduation. In addition, the college has built professional groups, such as medicine, economics and management. These professional groups have contributed to social and economic benefits.

Curriculum construction and applied technique-oriented institution. In order to implement the restructuring and development, City College of Wuhan University of Science and Technology focus on the construction of core professional curriculums. While designing course system, the college takes job requirements into consideration, determines the core jobs which are suitable for the students, clearly analyzes the core capabilities required and sets the curriculums around the core capabilities to enable the link of professional courses, students' knowledge and abilities, so that we could cultivate students' general and professional competitiveness of individual career development. The theoretical teaching hours is reduced while the hours of practice is increased. The practice hours of most majors, such as nursing, civil engineering, computer science and technology, mechanical engineering and automation, mechanical and electrical engineering and other majors, is up to $40 \%$. Moreover, the college attaches great importance on the curriculum construction, adopts the mode combining introduction and development, vigorously promotes the open courses on network resource, virtual laboratories, digital libraries and the construction of other digital resources and establishes the curriculum resource platform of a variety of learning resources. There are more than 10 provincial and collegiate open classes, more than 30 national and provincial micro lessons which have won rewards, more than 40 teachers' competition courses which have won rewards and more than 170 courses of teachers from famous universities. In addition, the college changes theoretical curriculums into innovation and entrepreneurship curriculums. Through Er-ya online learning platform, the students can choose elective or compulsory curriculums of College Students' Entrepreneurship Basis, Entrepreneurial Spirit and Practice, Entrepreneurial Management Practices, Business Plan Optimization, National Entrepreneurship and Students' Career Guidance.

Practical teaching and applied technique-oriented institutions. In order to overcome the phenomenon that the theoretical courses lack practical and the students' learned knowledge is of the enterprises' social reality, City College of Wuhan University of Science and Technology attaches great importance to all kinds of practical teaching. It establishes evaluation system of training programs for teachers of each major, procedures of practice class teaching, professional curriculum material construction, education and other aspects of practical training. In addition, the college attaches great importance to strengthen cooperation and exchanges with enterprises, sharing resources and complementing advantages. It promotes the College Training Model Reform, forming the guidance exploring the market demands of talents and the students' employment. By training high-qualified talents relying on industry, it will form the applied technique-oriented cooperation mechanism. For example, the college actively carries out school-enterprise cooperation on majors of Economics and Management. It cooperates with the Hai'er Group, Wuhan Iron and Logistics Company, Wuhan Port Group and other enterprises to establish a long-term stable off-campus internship training base. Thus, the students can practice and receive training through projects, which greatly improves the students' practical skills and technical application capabilities. According to the teaching needs, the college hires the well-known professional and technical talents within the province as visiting professors, enjoying the treatment of the teachers of the college and doing their duties. In 2015, Nursing Major of the college cooperates with Zhongnan Hospital of Wuhan University to build a internship training base which is a provincial internship training base. In the same year, Nursing Specialty Laboratory was also named provincial key experimental teaching demonstration center in Hubei Province. The college also communicates with Wuhan municipal government, closely linking the Yangtze River Delta, Pearl River Delta and the Wuhan East Lake Development Zone, Wuhan "8 + 1" city circle and a number of local governments and government talent platform and establishing internship bases including central enterprises, listed companies, 
Fortune 500 companies, state-owned enterprises and domestic top hospitals. In addition, it establishes long-term and stable cooperation with Marriott International, Taizhou International Hotel, Wuhan Railway Bureau, Huaqiao International Service Business Park, Sany, Zhongtian Iron and Steel Group and other public enterprises, as well as People's Hospital, Tongji Hospital, Union Hospital, Tianyou Hospital and some other 40 tertiary hospitals. In recent years, the employment rate of the students within the college is above $90 \%$.

Faculty construction and applied technique-oriented institutions. Teachers are engineers of human souls. Only strictly control the quality of teachers, can we provide strong support for the training of applied technique-oriented talents. A few years ago, City College of Wuhan University of Science and Technology began to pay attention to the formation of teachers' team. The hired young teachers in recent years, either undergraduates or graduates, graduate from 985 and 211 universities. This has been reported in Changjiang Daily, Chutian Metropolis Daily and Tencent and some other media. In addition, the college actively hired senior engineers and technicians with strong teaching ability, rich experience, high professional quality, successful entrepreneurs, entrepreneurs and other talents to teach the students courses of professional theories, practices, innovative and entrepreneurship. For instance, the Department of Urban Construction, Faculty of Economics and Management, Department of Medicine employ professional and part-time teachers. Most of them are retired professors and senior engineers of the well-known enterprises or hospitals in the province. The college focuses on training young teachers and organizes teaching competitions for young teachers. In 2015, the college organizes young teachers participated in the first Young Teachers' Teaching Competition of Three Schools (City College of Wuhan University of Science and Technology, WenHua College, The School of Art and Science of Hubei Normal University) and achieved excellent results. They make efforts to train excellent young teachers and qualified teachers to become teachers with practical experience and applied technique. They encourage teachers to actively participate in all types of school teaching competitions at all levels, all kinds of teaching competitions among national colleges, such as National Micro-class Teaching Competition, National FLTRP Cup "Teaching Star" Contest, "SFLEP Cup" Young Teachers' Teaching Competition, National Information Teaching Competition, National Aesthetic Exhibition Competition. They all gain excellent performance. These initiatives strengthen teachers' training and incentive teachers, improve their teaching ability and teaching level, improve the quality of teaching and create a teaching team with practical experience and applied technique.

Students' ability of adaption and applied technique-oriented institutions. Nowadays, science and technology rapidly advances. The fundamental way to the private higher education and independent universities' training is the students' technological capabilities. Therefore, while teaching students the basic professional knowledge and theories, we should also train their learned application skills and the competitiveness of social and professional development. City College of Wuhan University of Science and Technology has always attached great importance to various research projects, science and technology competitions at all levels. The school encourages the students to participate in various research projects and extra-curricular activities from the perspective of policy supporting, institutional incentives, the guidance of teachers, funding support, etc. The college focus on the national, provincial students' training programs on innovation and entrepreneurship, the extracurricular activities in science and technology with teachers' guide and "Challenge Cup" College Students' academic science and technology competitions and other activities. They organize the students to participate in research projects at all levels, research and technology contests and continuously improves the students' professional skills, innovation and practical ability. Since 2013, the college organizes the students to declare the projects of innovation and entrepreneurship for university students at all levels. During the past three years, 7 national innovation and entrepreneurship projects for university students and 17 provincial innovation and entrepreneurship projects for university students have been approved. Among these projects, Pengfou App, smart wardrobe, intelligent sensors multi-functional crib and other projects have won reward in National Undergraduates' Entrepreneurship Competition, National Undergraduates' IT Innovation and Entrepreneurship Competition, National Computer Design Contest. Moreover, the development and 
research of loquat wine, indoor air duct cleaning robot projects won state invention patents. In addition, the college made the best use of Challenge Cup competitions and extensively carries out variety of innovative entrepreneurship, science and technology competitions both inside and outside of the college. Each year, nearly $20 \%$ of the students participate in Challenge Cup competitions and the competition atmosphere is very intense. In 2015, the college organized 51 science and technology competitions and innovation and entrepreneurial activities. They organized the students to participate in extramural science and technology competitions and innovation and entrepreneurial activities about 39 times. Totally 3,000 people and 1,500 people respectively participated in the inside and outside innovation and entrepreneurial activities and technology competitions. There are more than 1,200 people involving in provincial and national scientific and technological competitions and innovation and entrepreneurial activities won rewards, particularly in national and provincial Challenge Cup competitions. From 2011 to 2015, our college ranked the first in provincial and national scientific and technological competitions and innovation and entrepreneurial activities, either from the perspective of the total awards, or the reward level. In 2016, three students, namely Bo-meng-xue Xia, Xu Liu and Yu-xin Yang gained Honorable Mention in MCM / ICM, which contributed to the international arena for the college. These achievements make great contributions to the college's way to train applied technique-oriented talents. The college will continue to play an active role in research projects, science and technology competitions, develop students' social responsibility, innovation and practical ability and improve the comprehensive quality, so that it will further enhance the level of teaching practice and the quality of applied technique-oriented talents. All these will finally provide a strong technical application support for our society.

\section{Conclusions}

Being the new force of higher education system, the private higher education institutions and independent colleges are responsible for regional economic and social development and provide professional talents. The state has made guidance for some universities' transformation to applied technical-oriented uones, which clearly contributes to the positioning and development of private higher education instituions and independent colleges. In particular construction period, private higher education instituions and independent colleges are facing important opportunities for development, as well as some factors and constraints, such as school funding, discipline professional development, teaching staff, cooperation of production, education and research. We should believe that if the majority of private higher education instituions and independent colleges seize the opportunities, overcome the difficulties and carry out reform during transformation, they will be able to construct modern universities with Chinese features.

\section{Acknowledgement}

This project is supported by Foundation for Scientific Research Projects of Hubei Provincial Department of Education in 2016.

\section{References}

[1] Yong-jun Tang, Jian-xiong Huang. Exploration into the Strategies of Application - oriented Universities [N]. China Education Daily, 2016, 3.

[2] Ming-dong Luo. "Transition" Development of Locally-run Universities: Basic Strategies and Major Approaches [J]. Journal of Chuxiong Normal University, 2015.

[3] Shi-gang Hu. Three Choices of the Local Colleges and Universities in Their Transformation [J]. Journal of Huanggang Normal University, 2015. 